\title{
INTEGRATED COASTAL MANAGEMENT IN VIETNAM: CURRENT SITUATION AND ORIENTATION
}

\author{
Nguyen Quoc Cuong ${ }^{1 *}$, Nguyen Van $\mathrm{Cu}^{2}$ \\ ${ }^{1}$ Hanoi University of Natural Resources and Environment, Vietnam \\ ${ }^{2}$ Institute of Geography-VAST, Vietnam \\ "E-mail: quoccuongwru@gmail.com
}

Received: 25-2-2013

\begin{abstract}
Vietnam is a coastal country located along the Vietnamese East Sea, has a coastline longer than 3,260 km, with two archipelagoes of Hoang Sa (Paracel islands) and Truong Sa (Spratly islands) and more than 3,000 big and small islands, with 28 coastal provinces and cities of 63 provinces and cities of the country. The coastal area accounts for 17\% of the total area of the country, and is inhabited by more than 20 million people, with the average population density of about 267 people per $\mathrm{km}^{2}, 1.2$ times higher than average density of the country.
\end{abstract}

Marine resources and advantages promise great prospects for the development of ocean and coastal economies of the country. However, along with the development and some achieved successes, we also face to many serious problems and challenges in marine environment, that tends to increase. Therefore, the application of integrated coastal management approach is of paramount importance for the sustainable development of ocean and coastal economic of Vietnam.

In recent years, with the support of the international organizations and countries from ASEAN region, Vietnam has been trying to enhance the application of integrated coastal management for the entire coastal area. Beside the achievements, practical application of integrated coastal management also indicates many difficulties and challenges, required to make timely solutions.

In this paper, we are looking forward to sharing information and the experience of integrated coastal management in Vietnam and do hope to receiving more supports from international and regional organizations for Vietnam to adopt successfully and efficiently integrated ocean and coastal management approach, and implement Vietnam's commitments in the implementation of sustainable development strategy for the East Asian Sea (SDS-SEA).

Key words: Integrated coastal management, sea, island, environment.

\section{FOREWORD}

Vietnam is a coastal country, located along the Vietnamese East Sea, has a coastline longer than $3,260 \mathrm{~km}$, with two archipelagoes of Hoang Sa (Paracel islands) and Truong Sa (Spratly islands) and more than 3,000 big and small islands. Marine resources and advantages brought by Vietnamese coast promise great prospects for the development of the country.
Therefore, development of marine economy is the preferred choice of Vietnam at the current time and future.

Since 1993, Vietnam has referred to the development of comprehensive marine economy oriented industrialization and modernization, to make major policy of building Vietnam into a strong seas nation and enriched from the sea. 
Vietnam has 28 coastal provinces and cities of 63 provinces/cities of the country, accounting for $17 \%$ of the total area of the country. The coastal areas are inhabitation of more than 20 million people, with an average population density of about 267 people per $\mathrm{km}^{2}$ which is 1.2 times higher than average density of the country.

During the recent years, social and economic activities in coastal Vietnam have been very exciting, and have achieved considerable successes in many areas, especially tourism, fisheries and marine transportation, processing industry and urban development. However, along with the development and successes, many serious problems of marine environment, marine resources and other marine values have arisen and tend to increase further.

Especially, the problems of marine environmental pollution, degradation of marine resources, natural habitat, natural disasters and environmental incidents, including climate change, are affecting the safety and social security In fact, one of the fundamental reasons leading to the above problems is the dispersion and separation of several components including marine ecosystems, coastal areas, lacking of policy, imbalance between exploitation and preservation. Each component is closely related to others. Thus, in order to efficiently exploit the potential of coastal areas while protecting and maintaining long-term values of the marine ecosystem and fixing the weaknesses of the natural resources management, it is necessary to apply the integrated management solutions. Besides, to provide products and services sustainably of the seas, coastal zones and estuaries, harmonious and optimal targets use is necessary.

Therefore, integrated coastal management is an urgent need for practical expanding in Vietnam to ensure sustainable development of marine economy. The implementation of integrated coastal management has achieved certain achievements, but also many difficulties and shortcomings should be removed and settled.

\section{CURRENT SITUATION AND ACHIEVEMENTS OF INTEGRATED COASTAL MANAGEMENT}

Integrated coastal management is a tool for administrations to identify and solve the problems of the exploitation and using of natural resources, ocean spatial planning and coastal development in general, and the problems of interdisciplinary, inter-locally and cross-border in particular. Integrated coastal management has been studied and formed from complementary needs and deficits management practices and marine environmental resources in the traditional sector, by territory, to exploit, use sustainably natural resources and environment for social economic development. The key principle of integrated coastal management in Vietnam which associates to the term "aggregate", is simply unity, integration and integrated into a common connection. These 3 main categories are the combination of coastal system's functions, integrated coastal zone policies, actions and management of shared resources values in the coastal area. It supports the industry, community agencies and implementation of its functions relating to the common use of the coastal zone, balancing the interests of different parties from the coastal zone, while maintaining the resources and values of the coastal zone for the next generation. It can be said that integrated coastal management approaches can achieve sustainable development in the coastal zone. Thus the integrated coastal management is the most appropriate choice to support and adjust the current management activities, for social and economic development, protection of marine natural resources, environment, and maintaining security sovereignty in coastal areas of Vietnam.

The integrated coastal management approach was recommended to apply sustainable development at the Summit on Environment and Global Development in Rio de Janeiro, 1992 [1]. The importance and practical needs of the model for integrated coastal management once again were confirmed at the Johannesburg summit 2002 on Sustainable Development. Until now many 
localities, nationalities, have adopted this approach, achieving high efficiency in the management of natural resources and environment, provided invaluable support for economic development and solving social welfare problems $[2,3,4]$.

In East Asia, the activities of integrated coastal management began about 30 years and are quite exciting. Typically, this area is densely populated, rich in natural resources and also facing many problems in natural resource and environmental use. From 1994 to 1999, GEF supported the Regional Program for Prevention and Management of the East Asia Sea (the World Maritime Organization) for 11 countries in the region, including Vietnam. The active purpose is for addressing the environmental problems of marine areas. At this stage, the program was developed two projects including integrated coastal management demonstration at regional level for Batangas (Philippines) and Xiamen (China). This program was later expanded to phase 2 (2000-2006), with a new name "Regional Partnership Programme for Environmental Management in East Asian Seas (PEMSEA), with financial support from GEF and the contribution of the member states, as well as other donors. In phase 2, six national demonstration projects on integrated coastal management were developed in 6 local points of 6 countries in the regional area, including $\mathrm{Da}$ Nang city, Vietnam [5, 6].

Some other Intergrated Coastal Management (ICM) projects implementing with technical supported from PEMSEA (called parallel ICM projects of PEMSEA) have been formed.

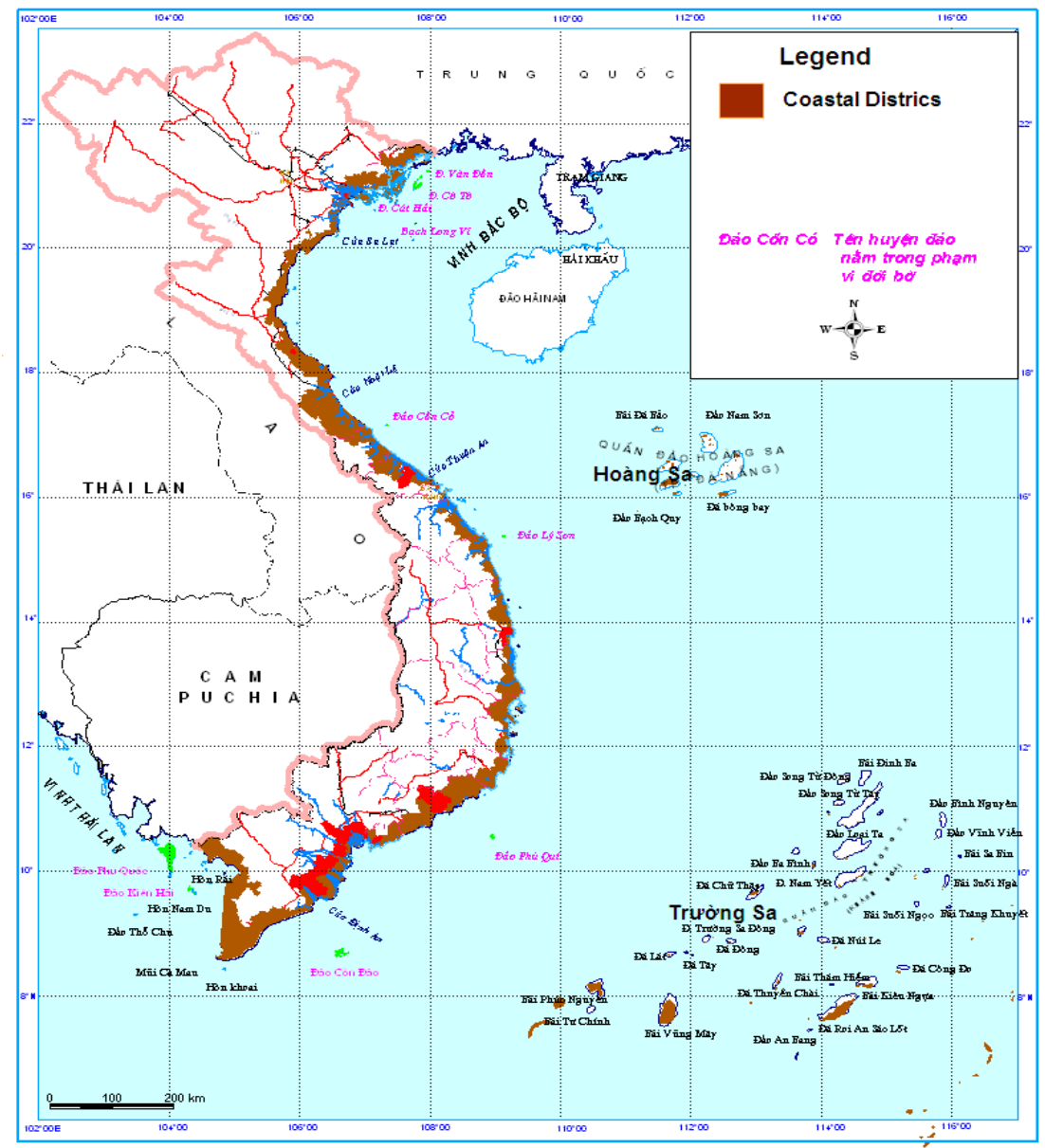

Fig. 1. Coastal Zone in Vietnam 
In addition, some management projects of environmental hot spots at sub-area and subregional level within the framework of PEMSEA using ICM approach have been developed and implemented, including project dealing with Oil spill in Thailand gulf area that Vietnam is one of member countries.

In Vietnam, "National pilot site project on ICM in Da Nang city" was the beginning of implementing ICM approach to marine natural resources and environment management. The project was achieved many successes. In order to promote the achievements, Da Nang city now continues applying this management method; focus on addressing some practical and specific issues.

With the support of government of The Netherlands, VNICZM project was developed and implemented at central level and provincial level from 2000 to 2006. At provincial level, ICM approach was applied at three pilot sites in three coastal provinces of Vietnam as Nam Dinh, Thua Thien - Hue, Ba Ria - Vung Tau. The achieved results were highly appreciated by the local government. The final result of VNICZM project is the important platform for proposing and developing ICM program in the North Central and Central coast toward year 2020, vision to 2030.

In addition, some other ICM projects were implemented in Quang Ninh, Hai Phong with funding support from NOAA and Vietnam Ministry of Natural Resources and Environment, and Ministry of Agriculture and Rural Development.

The initial implementation of ICM in Vietnam, particularly from year 2000 up till now in several local coastal provinces/cities such as Da Nang, Quang Nam, Nam Dinh, Hue, Ba Ria - Vung Tau, Quang Ninh and Hai Phong have obtained several important achievements such as:

Coordination mechanism including multisector cooperation is established, operated and verified in practice in Vietnam;

Strategy and long-term plan for ICM in some coastal provinces have been developed with the approval of these provincial People's
Committee. It has promoted the development of social economic based on maintaining the protection and sustainable use of natural resources and environment;

Improved human resources and staff capacity on ICM, as well as other related professional fields;

Established the integrated database resources on marine and coastal natural resources and environment effectively support for management work;

Developed and applied several important tools and technical guidelines for natural resources and environment management [6].

Improved awareness of the community on natural resources and environment and ICM.

Particularly, Prime Minister approved the Integrated Coastal Management Program for North central region and central coastal provinces until 2010 and orientations until 2020 (hereinafter called "Master Plan 158") on $9^{\text {th }}$ October 2007 [8]. For the period 2007 2011, the program has gained following significant achievements:

Developed and submitted to the Government to approve National Strategy and Action Plan on integrated coastal management.

Provided technical guidelines on ICM.

Disseminated training materials and program on ICM for the North Central and Central Coastal provinces.

Carried out a pilot program on integrated environmental monitoring in Thanh Hoa province; Built database system and general information on ICM in Ha Tinh province; Conducted the ICM planning and zoning in Thua Thien Hue province.

Developed database and integrated information system designated for ICM.

\section{LIMITATIONS OF ICM IN VIETNAM}

Besides above mentioned important results and achievements, the implementation of ICM projects in Vietnam has faced to some problems, details as follows: 
There are no appropriate and relevant policy framework and law in the management, exploitation and use of natural resources and environment. In fact, there are only specific regulations on activities management of each sector. Marine administrative boundary between provinces and cities has not been clearly defined. Provinces and cities are responsible for administration to the coastline. Responsibilities and obligations of some agencies, organizations and individuals in the management and use of resources, especially marine and seabed resources are unclear. Therefore, some hot issues related to natural resources management are not fully dealt with, leading to conflict in the exploitation and use of the resources.

Social economic strategies (national, regional and local) and development strategies for different sectors have been built. They strongly refer to the use and exploitation of natural resources and environment and common values in general as well as marine and coastal areas in particular. However, all strategies have mainly focused on economic aspect, usually giving priorities for some sectors and localities and not paying proper attention to the conservation of natural resources and environment and those common values that is the foundation for sustainable development. This fact leads to the gaps and overlaps in management, hindering overall development.

Sectoral and provincial planning still prevails; lack of integrated planning, there is no coordination among the ministerial levels and between central and provincial levels. Therefore mutual benefit has not been gained from the strategy, causing conflicts in the usage of resources, coastal zone space, obstructing sustainable development.

Legal documents also have similar problems such as gaps in the law enforcement deriving from policies, strategies, planning task, plans at all levels and there is not appropriate legal framework for ICM process.

Lack of information/management data service, especially information and data on biodiversity, environmental quality, marine rubbish, waste and impact from social economic activities on marine and coastal areas. The information/data have not been gathered, linked into the system and this system has not been standardized, causing difficulty in exploitation and using process.

A number of projects (or the content of the project) still focus on basic survey, totally scientific research rather than management aspect, so practical efficiency is low, while localities are not active participants, therefore the efficiency of the projects has not been made;

Training on human resources are unofficial and not updated, thus in reality it cannot meet the management need; officials who trained on ICM and related fields are not used effectively. Specific training documents on ICM that are used as basic materials for training in the Vietnam universities have not been made; No training program and documents on ICM for managers in natural resources and environment field and other related fields in Vietnam, lack of qualified and experienced experts on ICM;

Awareness of the ICM is not consistent, both in scientific and management aspects as well as both at central and local levels. Some localities have not been involved in projects and programs on ICM, thus their knowledge and awareness are limited.

The maintenance of ICM activities, especially coordination mechanisms, multisectoral cooperation are not taken into consideration properly after the projects finish [7].

\section{ORIENTATIONS AND SOLUTIONS FOR INTEGRATED COASTAL MANAGEMENT}

\section{Orientations for Integrated Coastal Management}

The Integrated Coastal Management Strategic towards 2020 and orientation 2030 is being built and approved. The Strategic goal is to implement the ICM method throughout Vietnam to protect, recover, maintain and develop resources and environment; support the 
socio - economic development. The main directions including:

Build and complete the legal and policy framework that supports the ICM in Vietnam.

Develop an effective multi-sectoral coordination mechanism at national level;

Build a team of managers, experts and engineering necessary technical e systems that support ICM;

Implement ICM in all coastal provinces in Viet Nam;

Create broad awareness among officials and people of the value of the coastal zone and coastal sustainable development needs through the application of ICM;

Strengthen international and regional cooperation on seas and islands to promote efficient exploitation of natural resources, marine environment for sustainable marine economic development;

By 2030, ICM will be institutionalized at the central and local levels; ICM is implemented in all coastal province and cities in Viet Nam forming a unified network to solve complex issues in management of natural resources and envionment throughout the coastal zone of Vietnam.

With the above directions, ICM will meet the wishes of the ministries and other stakeholders in use, exploitation, management and development of coastal Viet Nam, which are:

Protect and rehabilitate the coastal ecosystems such as: coral reefs, seagrass beds, mangrove forests and protective forests; Protect and develop the important wetlands such as: lagoon, estuaries, islands and marine ecological areas to high-biodiversity areas with a range of national, regional and international important levels;

Protect and replenish the coastal landscapes; maintain and promote the historical and cultural values for tourisms development and recreation.

A clean and safe coastal environment for human health and other marine ecosystems;
Prevent and minimize the loss of lives and properties (such as housing, public works and infrastructure) due to natural disasters.

Exclude the conflict of exploitation and use of coastal resources between sectors and localities; Ensure the harmonious, sustainable marine economic development.

Enhance the public understanding the coastal zone values as well as the responsibility for equitable sustainable use of natural resources, thus, improving people's quality of life.

\section{Solutions}

Vietnam Government continues to promote and strengthen the ICM implementation in coastal localities, while conduct activities related to refining the ICM policies and legislation at national level, such as:

ICM scaling up Program in North Central region and Central Coastal provinces towards 2020 , vision 2030. Currently, this program is in permission to be extended to the two coastal North and South areas of Vietnam, covering 28 coastal provinces and cities.

To develop the 5 - year ICM strengthening plans to to implement commitment of the Sustainable Development Strategic for East Asian Seas.

To integrate the ICM's contents into revised Marine Environment Law and other relevant policy and legislation documents;

To implement the overall project of basic survey and management of natural resources, marine environment by 2010 and towards 2020;

To establish the Department of ICM in some universities and expand the activities on training, teaching and researching ICM;

To strengthen the integrated and unified state management of Vietnam Administration of Seas and islands to perform and guide ICM activities.

\section{CONCLUSION}

The development of social economic activities in coastal areas have greatly affected 
the stability of marine and coastal areas in particular, should be recognized as a united system, which consist of different natural and artificial constituents, as follows: mangroves, forests, sand dunes, dikes, protection works, coastal roads, vegetation and other ecological resources.

Some main activities have caused instability of the coastal system in Vietnam. They can be reclaimation, change of purpose use of land and surface water is unplanned, beside they lack scientific basis and build construction, architecture and infrastructure (roads, buildings and structures) in the flush water, which have invasived function of the flush water as buffer zones between land and sea of the coastal systems, construction of protective works lack of scientific basis, breaking the natural laws of coastal processes; destruction of habitats and natural landscapes such as coastal mangroves, coral reefs, forests, and take action to reduce coastal protection and aesthetic value, thereof placer mining in the sand dunes and coastal issues upsetting the natural balance of coastal topography and vegetation destroyed carpet. Instability in the coastal area of Vietnam is increased further the impacts of natural disasters such as storms, floods, storm surges and sea level rise, including sea level rise due to climate change. Moreover, an entire people living in coastal areas are also threatened by the development too close to the sea when the lack of understanding of natural law in this area.

Therefore, the application of tools and mechanisms for ICM play important roles in the sustainable development of economic sectors of the marine and coastal area of Vietnam. In this paper, achievements by applying integrated coastal management from varied international funds, especially form PEMSEA in some coastal areas of Vietnam were summarized. Vietnam has been actively implementing ICM method with orientation and appropriate solutions.

From successful lessons and existing problems of ICM taking characteristics of Vietnam coastline into accounts, this paper also summarized main orientations and solutions need to be implemented in ICM of Vietnam for the future.

\section{REFERENCES}

1. UN Conference on Environment and Development, Reo de Janeiro, 1992. Rio Declaration on Environment and Development.

2. Intergovernmental Panel on Climate change, 1993. Preparing to meet the coastal challenges of the $21^{\text {st }}$ century. Conference report, World Coast Conference, p. 10.

3. The UN Millennium Development Goals, United Nation Millennium Summit in 2000.

4. Yves Henocque and Jacques Denis, 2001. Steps and Tools towards Integrated Coastal Area Management - Methodological Guid, Vol. 2.

5. PEMSEA Implementation Plan, 2003. The Sustainable Development Strategy for the Seas of East Asia (SDS-SEA).

6. Intergovernmental Oceanographic Commission of UNESCO, 2003. A reference Guide on the Use of Indicators for Integrated Coastal Management.

7. Heileman and Sherry, 2007. A Handbook for Measuring the progress and Outcomes of Integrated Coastal and Ocean Management. United Nations Educational, Scientific and Cultural Organization (UNESCO).

8. The Government Decision No 158/2007/GD-PM dated on 9 October 2007 of Primer Minister of Vietnam on "Master Plan of Integrated Costal Management in North - Central and Central coastal areas to 2010 and towards 2020”. 


\title{
QUẢN LÝ TỔNG HỢP ĐỚI BỜ TẠI VIẸT NAM: THỰC TRẠNG VÀ ĐINHH HƯƠNG
}

\author{
Nguyễn Quốc Cường ${ }^{1}$, Nguyễn Văn $C^{2}{ }^{2}$ \\ ${ }^{1}$ Trường Đại học Tài nguyên và Môi trường Hà Nội, Việt Nam \\ ${ }^{2}$ Viện Địa Lý-Viện Hàn lâm Khoa học và Công nghệ Việt Nam
}

TÓM TÄT: Việt Nam là một quốc gia biển với đường bờ biển dài hơn 3.260 km, có 2 quần đảo là Hoàng Sa, Truờng Sa và trên 3.000 các hòn đảo lớn nhỏ. Việt Nam có 28 tỉnh và thành phố ven biển dọc theo chiều dài đất nước tù Bắc đến Nam. Diện tích các khu vực ven biển chiếm đến $17 \%$ tổng diện tích cả nuơớc và là nơi cu trú của trên 20 triệu nguời. Mật độ dân cu tại các vùng ven biển trung bình là 267 người trên 1 km², lớn gấp 1,2 lần mật độ dân trung bình của cả nuớc.

Các nguồn tài nguyên và lợ thế tù biển mang đến những tiềm năng rất lớn cho phát triển kinh tế biển cho đất nước. Tuy nhiên, cùng với sự phát triển và các thành tưu đã đạt được, chúng ta cũng phải đối mặt với rất nhiều vấn đề nghiêm trọng và thách thức về môi truờng biển đang có chiều huớng gia tăng. Do vậy, cách tiếp cận quản lý tổng hợp đới bờ là rất quan trọng đối với việc phát triển bền vũng kinh tế biển của Việt Nam.

Trong nhũng năm gần đây, với sụ giúp đỡ tù các tổ chức quốc tế và các nuớc trong khu vưc ASEAN, Việt Nam đang tăng cuờng ứng dụng quản lý tổng hợp đới bờ cho toàn bộ vùng ven biển. Bên cạnh các thành tưu đạt được, việc áp dụng phương thức quản lý tổng hợp vùng bờ cüng gặp phải nhiều khó khăn và thách thức, đòi hỏi nhiều thời gian. Chính phủ và các địa phương có biển đã quan tâm và giành nguồn lực cho công tác quản lý tổng hơp đới bò̀, nhằm từng buớc xây dưng và hoàn thiện thể chế chính sách, nhân rộng mô hình và áp dưng thành công các giải pháp quán lý tổng hơp đói bò̀.

Trong bài báo này, chúng tôi muốn hướng tới việc chia sẻ thông tin và kinh nghiệm về ứng dụng quản lý tổng hợp đới bờ tại Việt Nam, hi vọng nhận được nhiều hỗ trọ hon nữa tù nhũng tổ chức quốc tế để Việt Nam áp dụng thành công và hiệu quả phuoong thức quản lý tổng hợp vùng biển và bờ biển, huớng tới thực hiện cam kết của Việt Nam trong chiến lực phát triển bền vững tại Biển Đông (SDS-SEA).

Tù khoá: Quản lý tổng hợp đới bờ, biển, đảo, môi truờng. 